\title{
Wolffia columbiana and W. globosa (Araceae) new to Britain
}

\author{
Richard V. Lansdown ${ }^{1 *}$, Geoffrey Kitchener ${ }^{2}$, Evan Jones ${ }^{3}$ \\ ${ }^{1}$ Associate Researcher, Natural History Museum, London; ${ }^{2}$ Halstead, Kent, UK; \\ ${ }^{3}$ Pevensey, Sussex, UK
}

*Corresponding author: Richard V. Lansdown: rvlansdown@gmail.com

This pdf constitutes the Version of Record published on $28^{\text {th }}$ February 2022

\begin{abstract}
In the course of surveys of ditches in the Pevensey Levels in October 2021, a large population of the non-native Wolffia columbiana $\mathrm{H}$. Karst. was found, new to Britain. Subsequent investigation showed $W$. columbiana to be widespread on the Pevensey and Gwent Levels and present in other grazing marsh ditch complexes in Somerset, West Sussex and Kent, while W. globosa (Roxb.) Hartog \& Plas was also found in the Gwent Levels. This paper describes the known distribution of W. columbiana in Britain, provides information on identification of different Wolffia species and considers the implications of this discovery for conservation of the native $W$. arrhiza (L.) Horkel ex Wimm.
\end{abstract}

Keywords: non-native; invasive; Duckweed; distribution; identification

\section{Introduction}

Wolffia L. is a genus of duckweed which includes the smallest flowering plant in the world and is distinguished from other duckweeds by a combination of swollen lower parts and the lack of roots. The genus includes 11 species worldwide (POWO, 2021) and, due to their small size, identification typically relies in part on microscopic characters. Since 2013, three non-native species have been recorded in Europe: $W$. columbiana H. Karst. (Schmitz et al. 2014), W. globosa (Roxb.) Hartog \& Plas (Kirjakov \& Velichkova 2013) and W. australiana (Benth.) Hartog \& Plas (FLORON, 2021) and it has always been likely that they would appear in the UK (e.g. Adams, 2019).

In September 2021 whilst surveying parts of the Pevensey Levels in East Sussex (v.c.14) to update records of the status of Potamogeton acutifolius, RVL and EJ found a population of Wolffia in one of the larger drains. Initially thought to be the native $W$. arrhiza (L.) Horkel ex Wimm., closer inspection revealed a number of characters suggesting that it might, in fact, be one of the alien species. Microscopic examination then confirmed its identity as W. columbiana (subsequently also confirmed by W. van der Ven), a first record of this non-native species in Britain.

Subsequent investigation showed $W$. columbiana to be present in a number of areas, with photographic evidence of its earlier occurrence; and W. globosa was found at a single site in the Gwent Levels (v.c.35). 
This paper describes the discovery of $W$. columbiana in Britain with information on its current known distribution, as well as the discovery of $W$. globosa, provides guidance on identification of Wolffia species and considers the potential period for which $W$. columbiana has been established in the country.

\section{Recording Wolffia in Britain in 2021}

Following initial discovery of $W$. columbiana in the ditch in the Pevensey Levels, the levels were re-visited in early October 2021, to attempt to locate populations of $W$. arrhiza. Sites with past records of $W$. arrhiza were visited but most were overgrown and shaded by reeds and willow scrub. Wolffia populations were only found at three sites and all involved $W$. columbiana (Table 1; Fig. 1).

A few days later a visit was made by RVL to the Gwent Levels and a total of six sites surveyed, representing all the main areas within the levels from which $W$. arrhiza had been reported. All sites supported populations of $W$. columbiana (Fig. 2) and one included plants subsequently identified as W. globosa. A visit was then made to the Somerset Levels (v.c.6) to look for Wolffia populations. Most of the ditches surveyed with past records were in a late stage of succession with no Wolffia found; however, Brock's Pill Rhyne which had no previous records of Wolffia had a complete carpet of $W$. columbiana. A request to A.J. Lockton and S. Buckingham for material from Kent then provided records of $W$. columbiana from seven sites, while a visit by RVL to an area of the Rother Valley on the East Sussex - Kent border failed to turn up any Wolffia at all, with some sites in too far advanced a stage of succession and others simply with Lemna and Spirodela species but no Wolffia. Edgecumbe Park in Devon, from which there was an incongruous record of $W$. arrhiza in 1974, was visited in early November 2021 but the only duckweed present was Lemna minuta.
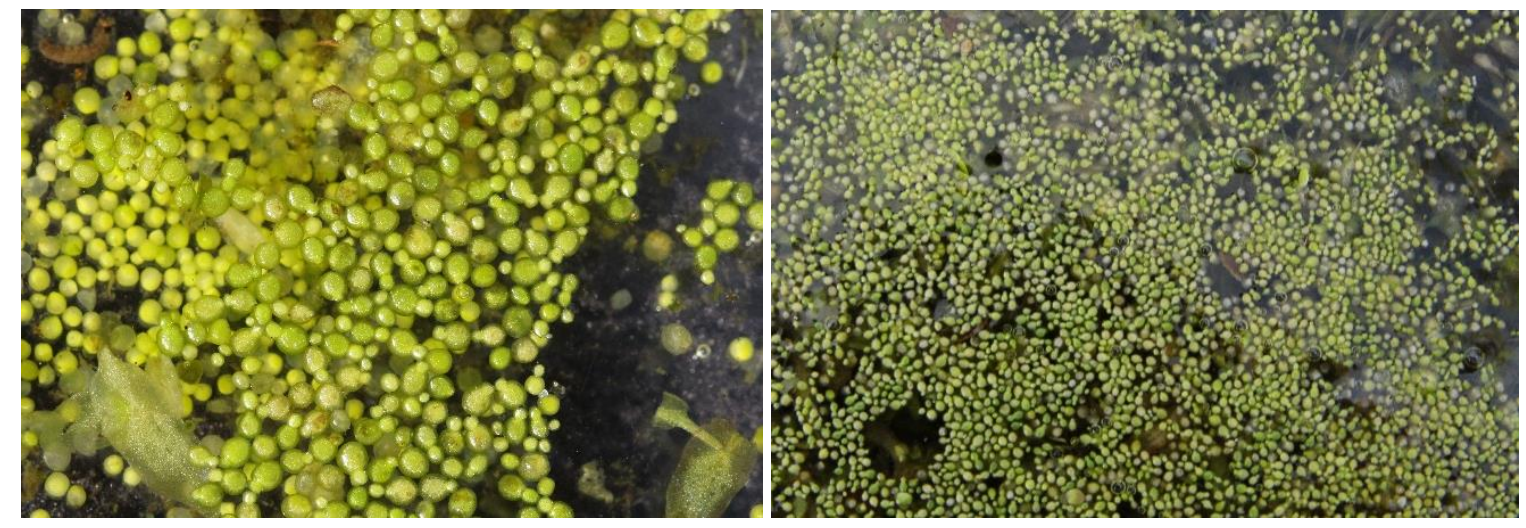

Figure 1. Floating groups of Wolffia columbiana fronds, showing variety in size, frond outline and the degree to which the differentiated margin is visible, as well as the very pale green colour (images: R.V. Lansdown).

In November 2021 a Wolffia population was sampled in a pond in east Surrey (v.c.17), this did not survive postage particularly well but appeared to include $W$. arrhiza, possibly as well as $W$. columbiana and W. globosa however identification is not absolutely certain (see also Discussion). W. arrhiza was also tentatively identified in a sample (also including $W$. columbiana) from ditch on the Dowells in sheep pasture near Kenardington (TQ9784.3126) in East Kent (v.c.15). 
Table 1. Records of $W$. columbiana in Britain

\begin{tabular}{|c|c|c|c|c|}
\hline v.c. & Grid Reference & Locality & Collector & Date \\
\hline 5 & ST3645.5216 & $\begin{array}{l}\text { Brock's Pill Rhyne, Somerset } \\
\text { Levels }\end{array}$ & R.V. Lansdown & 14.10 .2021 \\
\hline 13 & TQ0213 & Amberley Wild Brooks & $\begin{array}{l}\text { M. Cousins, J. } \\
\text { Whitman }\end{array}$ & 2017 \\
\hline 14 & TQ6079.0751 & ditch, Pevensey Levels & E. Jones (image) & 2018 \\
\hline 14 & TQ6731.0837 & ditch, Pevensey Levels & $\begin{array}{l}\text { R.V. Lansdown, E. } \\
\text { Jones }\end{array}$ & 22.9 .2021 \\
\hline 14 & TQ6889.0710 & ditch, Pevensey Levels & $\begin{array}{l}\text { R.V. Lansdown, E. } \\
\text { Jones }\end{array}$ & 22.9 .2021 \\
\hline 14 & TQ6769.0764 & ditch, Pevensey Levels & $\begin{array}{l}\text { R.V. Lansdown, E. } \\
\text { Jones }\end{array}$ & 22.9 .2021 \\
\hline 14 & TQ6079.0751 & ditch, Pevensey Levels & $\begin{array}{l}\text { R.V. Lansdown, E. } \\
\text { Jones }\end{array}$ & 23.9.2021 \\
\hline 14 & TQ6459.0419 & ditch, Pevensey Levels & $\begin{array}{l}\text { R.V. Lansdown, E. } \\
\text { Jones }\end{array}$ & 7.10 .2021 \\
\hline 14 & TQ6612.0606 & ditch, Pevensey Levels & $\begin{array}{l}\text { R.V. Lansdown, E. } \\
\text { Jones }\end{array}$ & 7.10 .2021 \\
\hline 14 & TQ6257.1058 & ditch, Pevensey Levels & $\begin{array}{l}\text { R.V. Lansdown, E. } \\
\text { Jones }\end{array}$ & 7.10 .2021 \\
\hline 14 & TQ6731.0837 & ditch, Pevensey Levels & $\begin{array}{l}\text { R.V. Lansdown, E. } \\
\text { Jones }\end{array}$ & 21.10 .2021 \\
\hline 14 & TQ6769.0764 & ditch, Pevensey Levels & $\begin{array}{l}\text { R.V. Lansdown, E. } \\
\text { Jones }\end{array}$ & 21.10 .2021 \\
\hline 15 & TR276631 & $\begin{array}{l}\text { fishing lake by the River } \\
\text { Stour below Pluck's Gutter }\end{array}$ & A.J. Lockton & 14.10 .2021 \\
\hline 15 & TQ9784.3126 & $\begin{array}{l}\text { ditches in sheep pasture near } \\
\text { Kenardington }\end{array}$ & S. Buckingham & 16.10 .2021 \\
\hline 15 & TQ9792.3128 & $\begin{array}{l}\text { ditches in sheep pasture near } \\
\text { Kenardington }\end{array}$ & S. Buckingham & 16.10 .2021 \\
\hline 15 & TQ9211.3010 & $\begin{array}{l}\text { recently cleaned roadside } \\
\text { ditch near Reading Street }\end{array}$ & S. Buckingham & 16.10 .2021 \\
\hline 15 & TR0105.2844 & $\begin{array}{l}\text { roadside pond near Brenzett } \\
\text { Corner }\end{array}$ & S. Buckingham & 16.10 .2021 \\
\hline 15 & TR0432.3188 & $\begin{array}{l}\text { ditches in arable near } \\
\text { Newchurch }\end{array}$ & S. Buckingham & 16.10 .2021 \\
\hline 15 & TR0763.2285 & $\begin{array}{l}\text { ditch on edge of arable, } \\
\text { Greatstone }\end{array}$ & S. Buckingham & 16.10 .2021 \\
\hline 35 & ST3968.8569 & $\begin{array}{l}\text { Middle Road Reen, Gwent } \\
\text { Levels }\end{array}$ & R.V. Lansdown & 12.10 .2021 \\
\hline 35 & ST3878.8512 & Elver Pill Reen, Gwent Levels & R.V. Lansdown & 12.10 .2021 \\
\hline 35 & ST3824.8486 & Parish Reen, Gwent Levels & R.V. Lansdown & 12.10 .2021 \\
\hline 35 & ST3770.8550 & Parish Reen, Gwent Levels & R.V. Lansdown & 12.10 .2021 \\
\hline 35 & ST3522.8337 & $\begin{array}{l}\text { Saltmarsh Reen, Gwent } \\
\text { Levels }\end{array}$ & R.V. Lansdown & 12.10 .2021 \\
\hline 35 & ST3727.8534 & Parish Reen, Gwent Levels & R.V. Lansdown & 12.10 .2021 \\
\hline
\end{tabular}




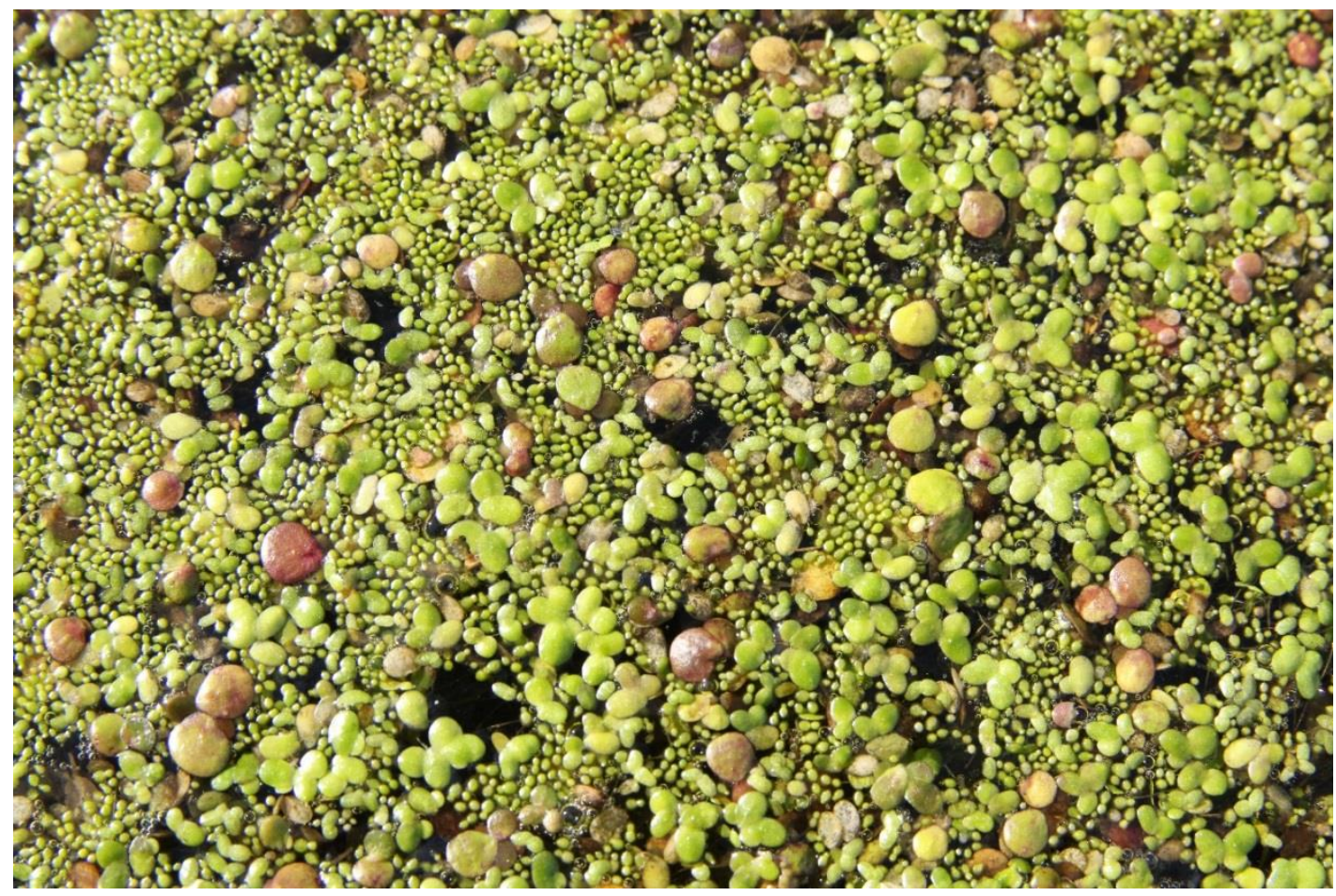

Figure 2. Wolffia columbiana in the Gwent Levels with Lemna gibba, $L$. minor, $L$. minuta and Spirodela polyrhiza (image: R.V. Lansdown).

\section{Identification}

All Wolffia species are very small; the largest is $W$. arrhiza, which is typically $0.7-1.3$ $\times 0.6-1.0 \mathrm{~mm}$ but is only slightly larger than $W$. australiana and $W$. columbiana; the smallest, which is also the smallest known flowering plant, is W. globosa which is typically $0.5-0.8 \times 0.2-0.4 \mathrm{~mm}$ (Table 2). They are composed of a photosynthetic upper part which is green and opaque, below which there is an expanded lower layer which is firm and may be green or colourless.

Table 2. Summary of identification characters of Wolffia species known from Europe (from Landolt, 1986; Landolt, 1994; Landolt, 2000; Bog et al., 2020)

\begin{tabular}{|l|c|c|c|c|}
\hline Character & W. arrhiza & W. australiana & W. columbiana & W. globosa \\
\hline Greatest width & $\begin{array}{c}\text { just below } \\
\text { surface }\end{array}$ & at surface & $\begin{array}{c}\text { well below } \\
\text { surface }\end{array}$ & $\begin{array}{c}\text { well below } \\
\text { surface }\end{array}$ \\
\hline Length (mm) & $\begin{array}{c}(0.5) 0.7-1.3 \\
(1.5)\end{array}$ & $\begin{array}{c}(0.5) 1.0- \\
1.3(1.5)\end{array}$ & $(0.5) 0.7-1.2(1.4)$ & $(0.4) 0.5-0.8(0.9)$ \\
\hline Width (mm) & $\begin{array}{c}(0.4) 0.6- \\
1.0(1.2)\end{array}$ & $\begin{array}{c}(0.3) 0.5- \\
0.7(0.8)\end{array}$ & $(0.5) 0.6-1.1(1.2)$ & $(0.3) 0.4-0.6$ \\
\hline Length : width & $1-1.33$ & $1.33-2$ & $1-1.33$ & $1.33-2.33$ \\
\hline Depth : width & $1-1.33$ & $2-3$ & $1-1.33$ & $0.75-1.33$ \\
\hline No. of stomata & $(0) 30-100$ & $50-80$ & $1-10(-30)$ & $8-25(35)$ \\
\hline Surface colour & bright green & bright green & pale green & pale green \\
\hline Surface & opaque & opaque & translucent & translucent \\
\hline Lower colour & translucent & $?$ & green & green \\
\hline
\end{tabular}


Species of Wolffia can be very difficult to identify, particularly as counting stomata appears to be unreliable without recourse to Scanning Electron Microscopy (SEM) (Schmitz et al., 2014; W. van der Wen pers. comm.). In spite of this, many species have been recorded outside their native range (Table 3 ), with species originating in the Americas (W. columbiana), Asia (W. globosa) and Australasia ( $W$. australiana) (Armstrong \& Thorne 1984, Landolt 1986, Mazzeo et al. 1993, Landolt 1994) all occurring in Europe (Kirjakov \& Velichkova 2013, Schmitz et al. 2014, FLORON 2021, Armstrong n.d.). An attempt has therefore been made here to provide guidance on all known species worldwide, while details are provided (Table 2) for the species known to occur in Europe.

Table 3. Summary of the native and non-native distribution of Wolffia species

\begin{tabular}{|c|c|c|}
\hline Species & native range & non-native range \\
\hline W. angusta & $\begin{array}{l}\text { Australia, Malaysia, Singapore } \\
\text { (Landolt, 1994, POWO, 2021) }\end{array}$ & \\
\hline W. arrhiza & $\begin{array}{l}\text { UK east to European Russia and } \\
\text { south to South Africa (POWO, 2021) }\end{array}$ & $\begin{array}{l}\text { Brazil, Japan, USA } \\
\text { (California) (POWO, 2021) }\end{array}$ \\
\hline W. australiana & $\begin{array}{l}\text { Australia, New Zealand (POWO, } \\
\text { 2021) }\end{array}$ & $\begin{array}{l}\text { Netherlands (FLORON, } \\
\text { 2021) }\end{array}$ \\
\hline W. borealis & Canada (POWO, 2021), USA & \\
\hline W. brasiliensis & $\begin{array}{l}\text { Canada to Paraguay, Uruguay, } \\
\text { northern Chile (POWO, 2021) }\end{array}$ & \\
\hline W. columbiana & Canada to Argentina (POWO, 2021) & $\begin{array}{l}\text { UK, Netherlands, Belgium, } \\
\text { France, Germany, India, } \\
\text { Italy, Japan (Kax et al., } \\
\text { 1978; Kadono, 2004; } \\
\text { Ardenghi et al., 2017; } \\
\text { FLORON, 2021, Niebler et } \\
\text { al., 2021; J. Geslin pers. } \\
\text { comm.) }\end{array}$ \\
\hline W. cylindracea & $\begin{array}{l}\text { Kenya to South Africa (POWO, } \\
\text { 2021) }\end{array}$ & \\
\hline W. elongata & Colombia (POWO, 2021) & \\
\hline W. globosa & $\begin{array}{l}\text { Pakistan to Japan, Malaysia (POWO, } \\
\text { 2021) }\end{array}$ & $\begin{array}{l}\text { Bulgaria, Colombia, } \\
\text { France, Germany, Japan, } \\
\text { Peru, USA (Kirjakov \& } \\
\text { Velichkova, 2013; Niebler } \\
\text { et al., 2021, POWO, 2021) }\end{array}$ \\
\hline $\begin{array}{l}\text { W. } \\
\text { microscopica }\end{array}$ & $\begin{array}{l}\text { Pakistan, India (Sree et al., 2014; } \\
\text { POWO, 2021) }\end{array}$ & \\
\hline W. neglecta & $\begin{array}{l}\text { Sri Lanka, India and Pakistan } \\
\text { (POWO, 2021) }\end{array}$ & \\
\hline
\end{tabular}




\section{Key to the identification of Wolffia species}

(from Landolt, 1986; Landolt, 1994; Sree et al., 2014; Landolt, 2000; Ward et al. 2021; Bog et al. 2013):

1 Fronds with a long appendage below, resembling a root but tapering into the frond

Fronds without an appendage below

W. microscopica

2 At least larger fronds with a prominent dorsal papule Fronds without a prominent dorsal papule

W. brasiliensis

3 Fronds $0.3-1 \mathrm{x}$ as deep as wide; vegetative apex of frond pointed and slightly upturned

W. borealis

Fronds $0.7-3 \times$ as deep as wide; vegetative apex of frond \pm flat

4 Fronds widest in centre of cross-section, well below the water surface, showing as a clearly differentiated margin $c$. one-fifth of width of frond seen from above (Fig. 3)

Fronds either of even width in cross-section or widest in upper part without clearly differentiated margin from above, or differentiated margin very narrow (roughly <one-tenth of width of frond seen from above)

5 Fronds $2-3 x$ as deep as wide Fronds $<1.5 \times$ as deep as wide

W. columbiana

6 Fronds $0.3-0.8 \mathrm{~mm}$ wide; $1.3-2 \times$ as long as wide; deep green on upper surface

Fronds $0.2-0.5 \mathrm{~mm}$ wide; $1.7-2.5 \times$ as long as wide; whitish green on upper surface with more intense green margins

W. australiana

W. angusta

7 Darker green upper part of fronds 1.33-2.5 $\mathrm{x}$ as long as wide, 1.5-3 $x$ as deep as wide with the greatest width at the water surface (almost no translucent margin visible from above) Darker green upper part of fronds 1-2.33 $x$ as long as wide, $0.75-1.5 \mathrm{x}$ as deep as wide with the greatest width below the water surface (at least laterally a translucent margin visible from above)

8 Fronds intensely green and mostly shiny at the surface with mostly $>30$ stomata

W. arrhiza Fronds not shiny, light green to rather intensely green with $<30$ stomata

9 Fronds with no translucent margin at the tip, with 15-30 stomata

W. cylindracea Fronds with a distinct translucent margin at the tip, mostly $<20$ stomata

W. globosa 
Of the species which have been recorded in Europe, W. columbiana is relatively easily recognised by the pale green, translucent upper part surrounded by the clearly differentiated lower layer which is distinctly visible from above due to the almost globose cross-section of fronds (Figs. 1 and 3). W. australiana is typically larger than the other species and narrower than all except $W$. globosa but is best recognised by the fact that fronds are parallel-sided in cross-section and can be much deeper than wide. W. globosa is typically much smaller than the other species, forming populations of uniformly tiny fronds which are narrower than W. arrhiza and W. columbiana. W. arrhiza (Fig. 4) is then recognised by the fact that it lacks the diagnostic characters of the other species. However, identification of plants can be far from straightforward.

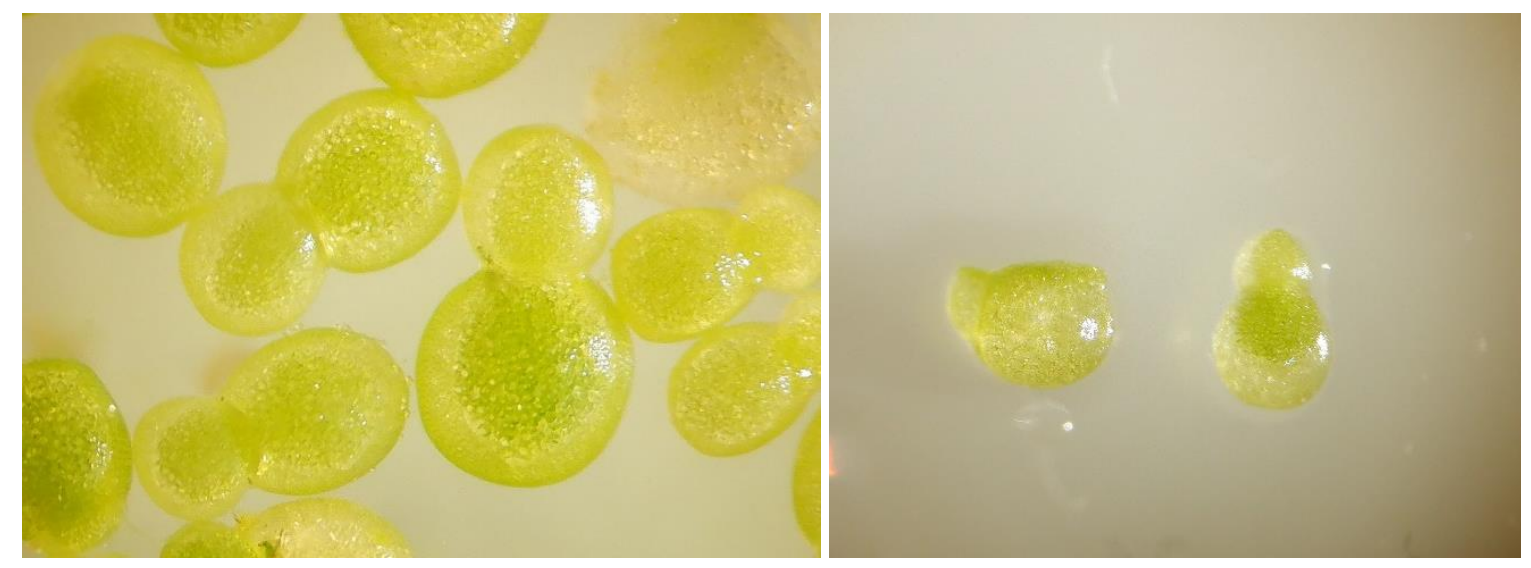

Figure 3. Wolffia columbiana showing the broad differentiated margin visible from above (left) and almost globose fronds (right: left-hand plant from the side, right hand from one end), material from the Pevensey Levels in October 2021 (images: R.V. Lansdown).

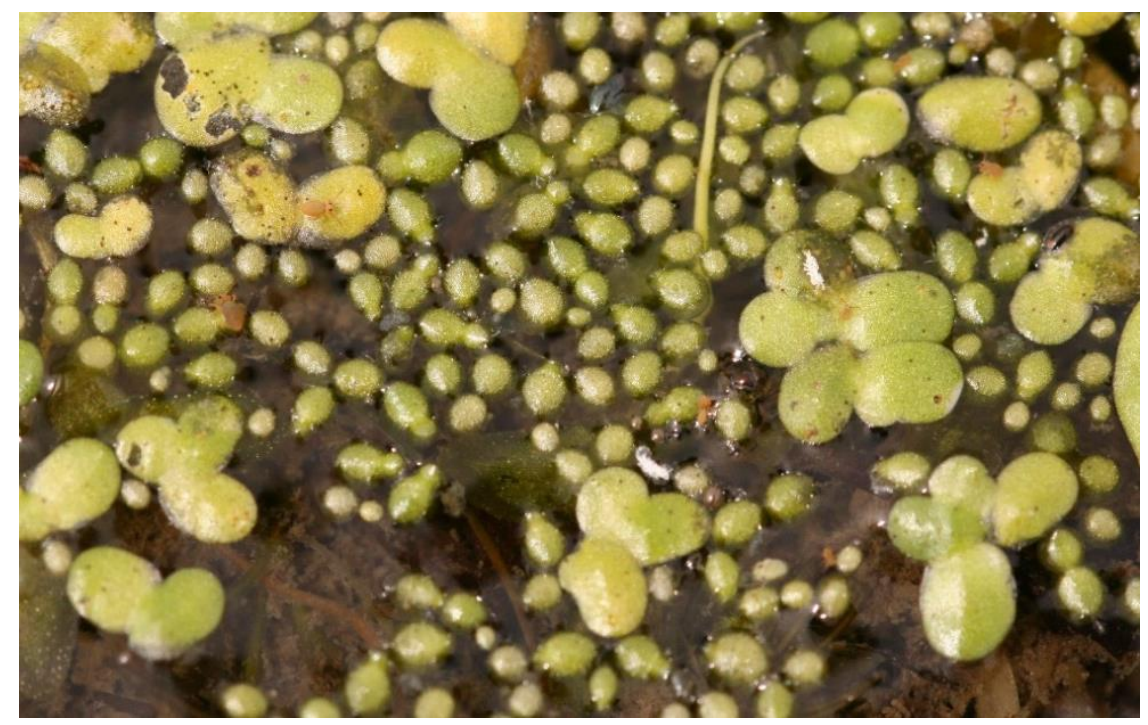

Figure 4. Wolffia arrhiza (with Lemna gibba) in a pond at the Hameau du Bouchet, Parc Naturel Régional de la Brenne, France showing no differentiated margin (image: R.V. Lansdown). 


\section{Discussion}

There has been an increase in new regional records of non-native duckweed species in recent years (e.g. Lansdown 2008, Lansdown et al. 2015, Rumsey \& Lansdown 2012) (Table 2). It is clear that these species are being moved around the world to an increasing extent and there is a need for increasing scrutiny to recognise new invasions when they occur. Wolffia columbiana has clearly become well-established in Europe, where it is now known from the UK (this study), Belgium, France (J. Geslin pers. comm.), Germany (Schou et al. in prep.), Italy (Ardenghi et al. 2017) and the Netherlands (FLORON 2021). Random sampling of Wolffia demonstrated that in Germany and the Netherlands W. columbiana now is much more frequent than the native W. arrhiza (Schmitz et al. 2016, W. van der Wen pers. comm.). W. australiana has also been recorded from the Netherlands where it is known from only a few sites (FLORON 2021), while W. globosa is known from single sites in France (Niebler et al. 2021), Germany (Schou et al. in prep.) and Bulgaria (Kirjakov \& Velichkova 2013).

The first published record of Wolffia in Britain was given by Trimen (1866), in relation to a population in a pond near Staines, Middlesex, although Gray (1866) mentioned having been shown specimens about 50 years earlier which were believed to have been collected from Putney Common. Until 2021, all populations were assumed to be $W$. arrhiza. However, the widespread occurrence of $W$. columbiana in 2021 strongly suggests that it has been established for some time; two sets of records are of particular note. The first record of Wolffia from the Pevensey Levels is from 1994 (BSBI Distribution Database); it would be surprising in an area so intensively botanised if it had been present in any abundance prior to that date. W. columbiana has certainly been established since 2018 (image EJ) and is now abundant (Fig. 5). It is credible that Wolffia arrhiza was never in the Pevensey Levels but that $W$. columbiana arrived at least as long ago as the 1990s. Similarly, the first record of Wolffia from the Gwent Levels was in 1982 and it seems credible that $W$. arrhiza was never present in the area, but that records involved $W$. columbiana or even W. globosa. In other areas, the Somerset Levels (v.c.5 and v.c.6), East Kent (v.c.15) and the Thames floodplain (in v.c.17), Wolffia populations were all first recorded in the $19^{\text {th }}$ or the early part of the $20^{\text {th }}$ century and are likely to have involved $W$. arrhiza; however, all except v.c.17 have been shown since to support $W$. columbiana. Photographs of material from the Lewes area show that $W$. columbiana was present there at least in 2011 (Lyons, 2011).

When the decade in which Wolffia populations were recorded for the first time in a hectad is compared, there is a striking increase in the middle of the $20^{\text {th }}$ century and a second in the early 1990s (Fig. 6). It is tempting to think that at least part of one of these increases could be due to the arrival and spread of $W$. columbiana, although the 1950 peak is likely to be at least partly linked to fieldwork for the first atlas (Perring \& Walters, 1962).

Duckweeds show a remarkable capacity for dispersal, and $W$. columbiana has even been shown to remain viable when transported through ingestion by birds (Silva et al., 2018). Whether by such means or by transfer by attachment to waterfowl, it is feasible that avian transmission may account for the Pevensey Levels and Romney Marsh introductions. The occurrence of $W$. columbiana in Italy in 2016 was believed to have derived from a neighbouring fish farm, where importation of fish cultures may carry Wolffia as contaminants (Ardenghi et al., 2017). Inspection 
of the bases of plants of Pistia stratiotes and other non-native plant species sold in garden centres shows that many include non-native duckweeds such as Lemna aequinoctialis, L. minuta, L. valdiviana and Spirodela oligorrhiza (Rumsey \& Lansdown, 2012; RVL unpublished data). It is highly likely that the inadvertent or deliberate introduction of cultivated aquatic plants to the wild brings with it some of these non-native duckweeds.

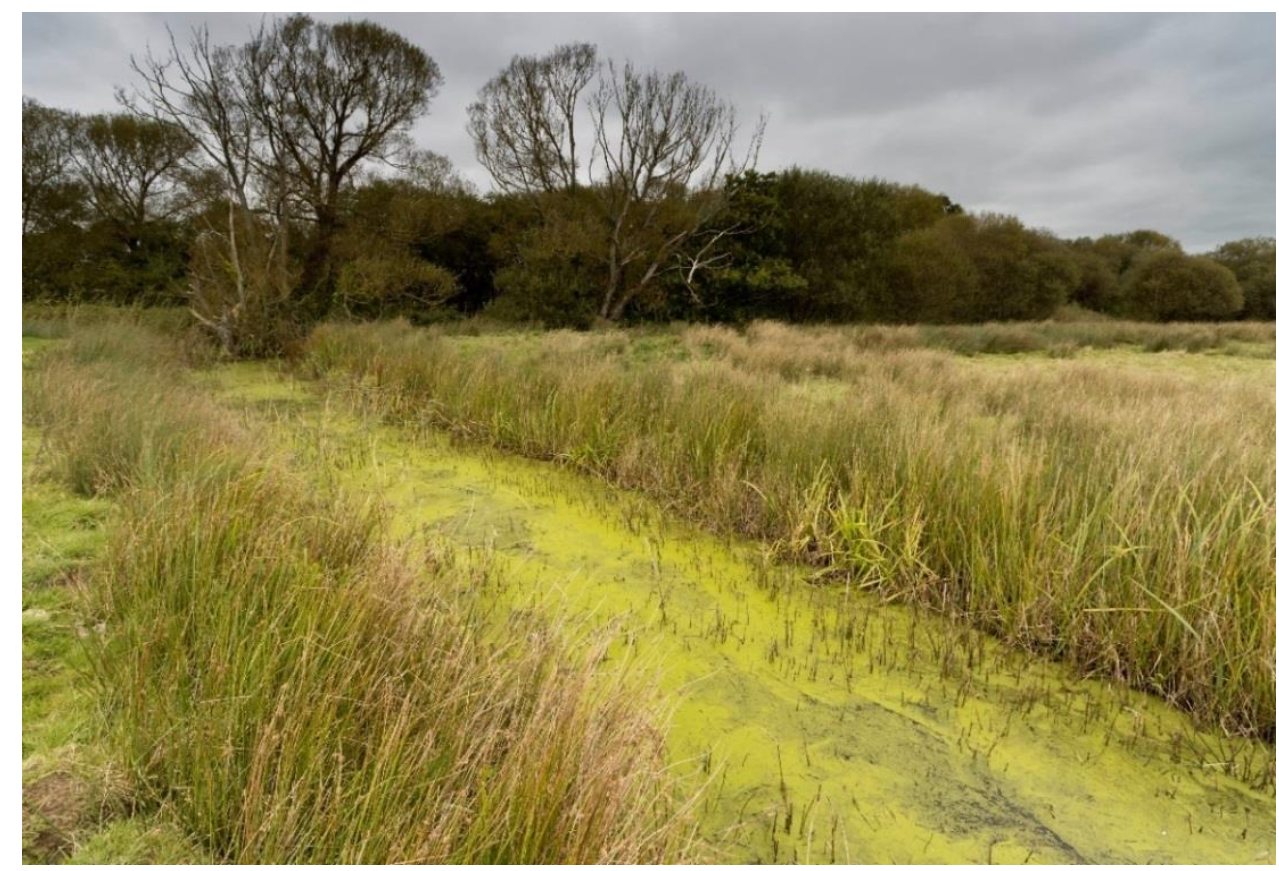

Figure 5. A ditch in the Pevensey Levels with a monospecific population of Wolffia columbiana, showing the characteristic pale green colour of populations (image: E. Jones).

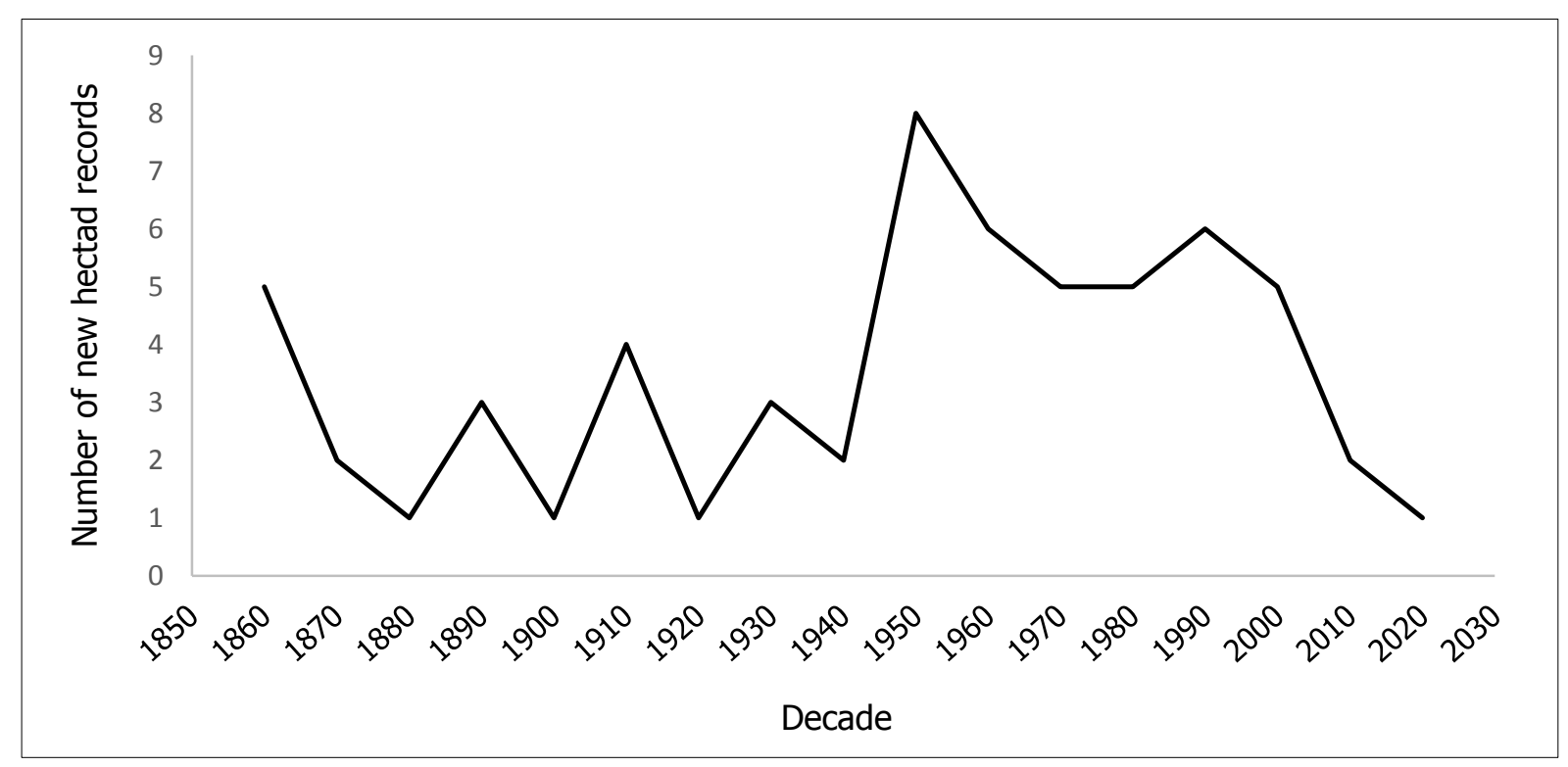

Figure 6. Number of new hectad records of Wolffia arrhiza per decade in Britain. 
Images taken from the side of plants of $W$. columbiana, which have a globose cross-section, a differentiated margin when viewed from above and translucent upper cells, from the Gwent Levels (Fig. 3) more closely resemble those of $W$. arrhiza given by Landolt (1994, Fig. 2h) than those of W. columbiana (Landolt 1994, Fig. 20), particularly in the extent of the differentiated upper part and the degree to which the upper part is domed. This character therefore appears to be unreliable.

Wolffia species are very small and there are only a very small number of features which can serve for morphological identification, particularly as counts of the number of stomata appear to be unreliable without recourse to SEM. Counts of stomata using a dissecting microscope suggest that populations of $W$. columbiana recorded in north-western France had $<10$ stomata per frond, whereas counts from material from the Gwent, Pevensey and Somerset Levels typically had (8-)10-20(25). Schmitz et al. (2014) using SEM noted that counts from German populations found 3-14 stomata per frond (mean 5.5) and Dutch populations 3-11 per frond (mean 6.4). Landolt (1986) notes that "In Florida, there are clones of W. columbiana which have up to 30 stomata and therefore resemble $W$. arrhiza". The difference in counts in Europe could be because $W$. columbiana has spread within each country from one or only a few introductions, with most reproduction being vegetative and as a result, the populations involve a small number of clones. Apart from gross and typically unequivocal morphological structures, such as presence of a dorsal papule in $W$. brasiliensis or tapering into a root-like structure below in W. microscopica, most identification is based on poorly-defined descriptive terms or relative characters, such as "spherical", "ellipsoid" or "boat-shaped" (Landolt 1986), "Fronds intensely green and mostly shiny at the surface" (Landolt 1994), relative length to width, width to depth etc. There is also typically an overlap in characters presented and as the plants are so small, even small overlaps can render characters almost useless. It is therefore very difficult to achieve confident and, above all, reliable identification of Wolffia species other than those with particularly distinctive characters, such as W. brasiliensis, W. columbiana and W. microscopica. As noted by Landolt (1994) there is a need for more research.

The most striking aspect of the survey of Wolffia populations following the discovery of $W$. columbiana in the Pevensey Levels in 2021 was the very limited number of populations of $W$. arrhiza recorded. There is an urgent need to re-visit Wolffia populations to confirm the identity of the species involved, document all nonnative species present and as a high priority, confirm the distribution and conservation status of $W$. arrhiza.

\section{Acknowledgements}

The authors would like to thank Wim van der Wen for confirming the identify of $W$. columbiana and for background information on its distribution in continental Europe, Julian Geslin for information on French records, Pete Stroh for detail of UK records, Sue Buckingham and Alex Lockton for both collecting and sending material and to Mags Cousins for sight of her photograph of $W$. columbiana from Amberley Wild Brooks. 


\section{References}

Adams, K. 2019. Wolf at the door! Essex Botany 9: 9-11.

Ardenghi, N.M.G., Armstrong, W.P. \& Paganelli, D. 2017. Wolffia columbiana (Araceae, Lemnoideae): first record of the smallest alien flowering plant in southern Europe and Italy. Botany Letters 164(2): 121-127.

Armstrong W.P. \& Thorne R.F. 1984. The genus Wolffia (Lemnaceae) in California. Madrono 31(3): 171-179. Available at:

https://www.biodiversitylibrary.org/page/47946052\#page/595/mode/1up.

Armstrong, W.P. (n.d.). Wayne's Word: Lemnaceae. Available at: https://www2.palomar.edu/users/warmstrong/1wayindx.htm

Bog, M., Appenroth, K.J. \& Sree, K.S. 2020 Key to the determination of taxa of Lemnaceae: an update. Nordic Journal of Botany 38(8): 1-12.

Bog, M., Schneider, P., Hellwig, F., Sachse, S., Kochieva, E.Z., Martyrosian, E., Landolt, E. \& Appenroth, K.J. 2013. Genetic characterization and barcoding of taxa in the genus Wolffia Horkel ex Schleid. (Lemnaceae) as revealed by two plastidic markers and amplified fragment length polymorphism (AFLP) Planta 237: 1-13. DOI 10.1007/s00425-012-1777-9.

FLORON 2021. Verspreidingsatlas Vaatplanten: Wolffia columbiana H. Karst. [accessed 16 November 2011]. Available at:

https://www.verspreidingsatlas.nl/6975

Gray, J.E. 1866. A new British station of Wolffia arrhiza. Journal of Botany 4: 263264.

Kadono, Y. 2004. Alien Aquatic Plants Naturalized in Japan: History and Present Status. Global Environmental Research 8(2): 163-169.

Kax, A. M., Bakaya, U. \& Javeid, G.N. 1978. Wolffia papulifera Thomps. and W. columbiana Karsten - Two New Plant Records for India. The Indian Forester 104 (4): 282-285.

Kirjakov I. \& Velichkova K. 2013. Wolffia globosa (Roxburgh) Hartog et Plas (Lemnaceae): a New Species in Bulgarian Flora. Journal of Biological \& Scientific Opinion 1(4): 356-357. Available at: https://jbsoweb.com/admin/php/uploads/81 pdf.pdf.

Landolt, E. 1986. Biosystematic investigations in the family of duckweeds (Lemnaceae), 2. The family of Lemnaceae - a monographic study. Volume 1. Veröffentlichungen des Geobotanischen Institutes der Eidg. Techn. Hochschule, Stiftung Rübel, in Zürich 71.

Landolt, E. 1994. Taxonomy and Ecology of the Section Wolffia of the Genus Wolffia (Lemnaceae). Zeitschrift: Berichte des Geobotanischen Institutes der Eidg. Techn. Hochschule, Stiftung Rübel: 60: 137-151. Available at: http://doi.org/10.5169/seals-377790.

Landolt, E. 2000. Lemnaceae Gray. In: Flora of North America Editorial Committee (eds.) Flora of North America North of Mexico, Vol. 22: Magnoliophyta:

Alismatidae, Arecidae, Commelinidae (in Part), and Zingiberidae. New York and Oxford. Available at:

http://www.efloras.org/florataxon.aspx?flora id=1\&taxon id=10488.

Lansdown, R., Anastasiu, P., Barina, Z., Bazos, I., Çakan, H., Cakovic, D., Delipetrou, P., Matevski, V., Mitić, B., Ruprecht, E., Tomović, G., Tosheva, A. \& Király, G. 2015. Review of Alien Freshwater Vascular Plants in South-east Europe. In: Rat, M., Trichkova, T., Scalera, R., Tomov, R. \& Uludag, A., eds. 
ESENIAS Report 2015 - State of the Art of Invasive Alien Species in SouthEastern Europe. University of Novi Sad Faculty of Sciences, Department of Biology and Ecology, Novi Sad, Serbia. East and South European Network for Invasive Alien Species, Sofia, Bulgaria.

Lansdown, R.V. 2008. Red duckweed (Lemna turionifera Landolt) new to Britain. Watsonia 27(2):127-130.

Lyons, G. 2011. The Lyons Share: The UK's smallest vascular plant. Available at: http://analternativenaturalhistoryofsussex.blogspot.com/2011/09/ukssmallest-vascular-plant.html.

Mazzeo N., Rodríguez R. \& Rondanelli M. 1993. El género Wolffia Horkel ex Schleid. (Lemnaceae) en la flora acuática de Chile. Gayana Botanica 50(2): 67-68.

Niebler, F., Delaumône, P. \& Fried, G. 2021. Découverte de Wolffia globosa (Roxb.) Hartog \& Plas (Araceae) dans l'Hérault (France), espèce nouvelle pour la France. Société botanique d'Occitanie: Carnets Botaniques 52. Available at: https://sbocc.fr/wp-content/uploads/2021/05/Carnetsbotaniques-n\%C2\%B052.pdf.

Perring, F.H. \& Walters, S.M. 1962. Atlas of the British Flora. London: Thomas Nelson \& Sons.

POWO 2021. Plants of the World Online. Facilitated by the Royal Botanic Gardens, Kew. [accessed 28 November 2021]. Available at: http://www. plantsoftheworldonline.org/

Rumsey, F. \& Lansdown, R. 2012. Identification: Duckweeds and other simple floating aquatic plants. British Wildlife 23(5): 326-334.

Schmitz, U., Köhler, S. \& Nesemann, H. 2016. Neue Nachweise der Kolumbianischen Zwergwasserlinse Wolffia columbiana in Europa - Bei wie vielen vermeintlichen Vorkommen von Wolffia arrhiza handelt es sich in Wirklichkeit um den Neophyten? [New Records of Columbian Watermeal Wolffia columbiana in Europe - How many of the assumed occurrences of Wolffia arrhiza are in reality the alien species?]. Veröffentlichungen des Bochumer Botanischen Vereins 8 (1): 1-10. Available at:

https://www.botanikbochum.de/publ/OVBBV8 1 Schmitz Koehler Nesemann Wolffia columbian a.pdf.

Schmitz, U., Köhler, S. \& Hussner, A. 2014. First records of American Wolffia columbiana in Europe - Clandestine replacement of native Wolffia arrhiza? BioInvasions Records 3(4): 213-216.

Schou, J.C., Moeslund, B., van de Weyer, K., Lansdown, R.V., Wiegleb, G., Holm, P., Baastrup-Spohr, L. \& Sand-Jensen, K. In prep. A guide to the aquatic plants of Central and Northern Europe.

Silva, G.G., Green, A.J., Weber, V., Hoffmann, P., Lovas-Kiss, A., Stenert, C. \& Maltchik, L. 2018. Whole angiosperms Wolffia columbiana disperse by gut passage through wildfowl in South America. Biology Letters. 14: 20180703. http://dx.doi.org/10.1098/rsbl.2018.0703

Sree, K.S., Maheshwari, S.C., Boka, K., Khurana, J.P., Keresztes, Á. \& Appenroth, K.J. 2014. The duckweed Wolffia microscopica: A unique aquatic monocot. Flora 210: 31-39. http://dx.doi.org/10.1016/j.flora.2014.10.006. 
Trimen, H. 1866. Wolffia arrhiza, Wimmer, in England. Journal of Botany 4: 219223.

Ward, D.B. \& Hall, D.W. 2010. Keys to the flora of Florida - 25, Lemnaceae. Phytologia 92(2): 241-248.

Copyright retained by author(s). Published by BSBI under the terms of the Creative Commons Attribution 4.0 International Public License.

ISSN: $2632-4970$

https://doi.org/10.33928/bib.2022.04.014 